\title{
Pseudoephedrine Sulfate
}

National Cancer Institute

\section{Source}

National Cancer Institute. Pseudoephedrine Sulfate. NCI Thesaurus. Code C47696.

The sulfate salt form of pseudoephedrine, a phenethylamine and a diastereomer of ephedrine with sympathomimetic property. Pseudoephedrine sulfate displaces norepinephrine from storage vesicles in presynaptic neurones, thereby releasing norepinephrine into the neuronal synapses where it stimulates primarily alpha-adrenergic receptors. It also has weak direct agonist activity at alpha- and beta- adrenergic receptors. Receptor stimulation results in vasoconstriction and decreases nasal and sinus congestion. 